\title{
DI-Leu16-IL2 Immunocytokine
}

National Cancer Institute

\section{Source}

National Cancer Institute. DI-Leu16-IL2 Immunocytokine. NCI Thesaurus. Code C78451.

A recombinant fusion protein consisting of de-immunized and humanized anti-CD20 monoclonal antibody Leu16 fused to human cytokine interleukin-2 (IL2) with potential antineoplastic activity. The antibody moiety of DI-Leu16-IL2 immunocytokine binds to tumor cells expressing the CD20 antigen, which may result in an antibody-dependent cellmediated cytotoxicity (ADCC) towards CD20-expressing tumor cells; the localized IL2 moiety of this fusion protein may stimulate natural killer (NK) and T-lymphocyte mediated immune responses, enhancing the ADCC response. De-immunization involves the modification of potential helper T cell epitopes that bind to MHC class II molecules; humanization involves combining recombinant murine variable $(V)$ regions with human immunog lobulin light and heavy chain constant regions. CD20 antigen, a hydrophobic transmembrane protein located on normal pre-B and mature $B$ lymphocytes, is overexpressed by various cancer cell types. 